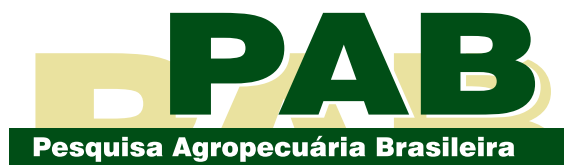

ISSN 1678-3921

Journal homepage: www.embrapa.br/pab

For manuscript submission and journal contents, access: www.scielo.br/pab

Lucas Felisberto Pereira(1) (iD),

Walter Quadros Ribeiro Junior ${ }^{(2 \otimes)}($ iD, Maria Lucrécia Gerosa Ramos ${ }^{(3)}$ (D), Nicolas Zendonadi dos Santos ${ }^{(4)}$ (iD), Guilherme Filgueiras Soares(3) (iD, Raphael Augusto das Chagas Noqueli Casari $^{(3)}$ (D),

Onno Muller(4) (iD,

Cássio Jardim Tavares ${ }^{(1)}$ (iD,

Éder de Souza Martins ${ }^{(2)}$ (iD,

Uwe Rascher ${ }^{(4)}$ (iD),

Cristiane Andréa de Lima Guimarães ${ }^{(3)}$ (D), André Ferreira Pereira ${ }^{(2)}$ (D),

Liliane Márcia Mertz-Henning(5) (D) and

Carlos Antonio Ferreira de Sousa ${ }^{(6)}$ (DD

(1) Instituto Federal Goiano, Fazenda Vereda do Canto, GO-453, Km 2.5, Distrito Agroindustrial Posse, CEP 73900-000 Posse, GO, Brazil.

E-mail: lucas.felisberto@ifgoiano.edu.br. cassio.tavares@ifgoiano.edu.br

(2) Embrapa Cerrados, Rodovia BR-020, Km 18, Caixa Postal 08223, CEP 73310-970 Planaltina, DF, Brazil.

E-mail: walter.quadros@embrapa.br, eder.martins@embrapa.br,

andre.ferreira@embrapa.br

(3) Universidade de Brasília, Faculdade de Agronomia e Medicina Veterinária, Campus Universitário Darcy Ribeiro, CEP 70910-900 Brasília, DF, Brazil.

E-mail: lucreciaunb@gmail.com, soaresgf30@gmail.com, casari.raphael@gmail.com

(4) Forschungszentrum Jülich $\mathrm{GmbH}$, Jülich, Germany.E-mail: n.zendonadi@fz-juelich.de, o.muller@fz-juelich.de, u.rascher@fz-juelich.de

(5) Embrapa Soja, Rodovia Carlos João Strass, $\mathrm{s} / \mathrm{n}^{\circ}$, Acesso Orlando Amaral, Distrito de Warta, Caixa Postal 231, CEP 86001-970 Londrina, PR, Brazil. E-mail: Liliane.henning@embrapa.br

(6) Embrapa Meio-Norte, Avenida Duque de Caxias, o 5.650, Caixa Postal 001, Buenos Aires, CEP 64008-780 Teresina, PI, Brazil. E-mail: carlos.antonio@embrapa.br

$\bowtie$ Corresponding author
Thematic Issue - Regional Agrominerals/ Original Article

\section{Physiological changes in soybean cultivated with soil remineralizer in the Cerrado under variable water regimes}

\begin{abstract}
The objective of this work was to evaluate the influence of the soil remineralizer fine-graded mica schist (FMS) on soybean (Glycine max) physiology, yield, and grain quality under different water regimes (WRs) in the Brazilian Cerrado. The experiment was conducted under field conditions for two years, using four WRs and three treatments: mica schist, conventional fertilization, and control. In 2017 and 2018, the following WRs were evaluated: WR1, WR2, WR3, and WR4, corresponding to a mean value of 100, 65, 44, and $28 \%$ of crop evapotranspiration replacement, respectively. Photosynthesis, stomatal conductance, transpiration, internal $\mathrm{CO}_{2}$ concentration, effective quantum yield of photosystem II (PSII) $\left(\mathrm{F}_{\mathrm{v}}{ }^{\prime} / \mathrm{F}_{\mathrm{m}}{ }^{\prime}\right)$, quantum yield (PSII) $\left({ }_{\mathrm{FSII}}\right)$, and electron transport rate reduced as a function of the advanced phenological stage of soybean and the reduction in WR. Grain quality was only affected by the WR. The mica schist was statistically similar to conventional fertilization and the control in 2017 and 2018. Yield decreased due to the anticipation of soybean phenological age and WR, but there were no differences between the three treatments in 2017 and 2018. The reduction in soybean yield is attributed to stomatal closure, loss of photoprotective capacity, and damage to the photosynthetic machinery caused by drought.
\end{abstract}

Index terms: Glycine max, line source, mica schist, photosynthesis, water stress.

\section{Alterações fisiológicas de soja cultivada com remineralizador de solo no Cerrado sob regimes hídricos variáveis}

Resumo - O objetivo deste trabalho foi avaliar a influência do remineralizador de solo finos de mica xisto (FMS) na fisiologia, na produtividade e na qualidade de grãos de soja (Glycine max) em diferentes regimes hídricos (RHs), no Cerrado brasileiro. O experimento foi conduzido em condições de campo durante dois anos, tendo-se utilizado quatro RHs e três tratamentos: mica xisto, adubação convencional e controle. Em 2017 e 2018, foram avaliados os seguintes RHs: RH1, RH2, RH3 e RH4, que correspondiam ao valor médio de $100,65,44$ e $28 \%$ da reposição da evapotranspiração da cultura, respectivamente. A fotossíntese, a condutância estomática, a transpiração, a concentração interna de $\mathrm{CO}_{2}$, o rendimento quântico efetivo do fotossistema II (FSII) $\left(\mathrm{F}_{\mathrm{v}}{ }^{\prime} / \mathrm{F}_{\mathrm{m}}{ }^{\prime}\right)$, o rendimento quântico (FSII) $\left(\phi_{\mathrm{FSII}}\right)$ e a taxa de transporte de elétrons reduziram em função do avanço da fase fenológica da soja e da redução do RH. A qualidade dos grãos foi afetada apenas pelo RH. O mica xisto foi estatisticamente semelhante à adubação convencional e ao controle em 2017 e 2018. A produtividade reduziu devido à antecipação 


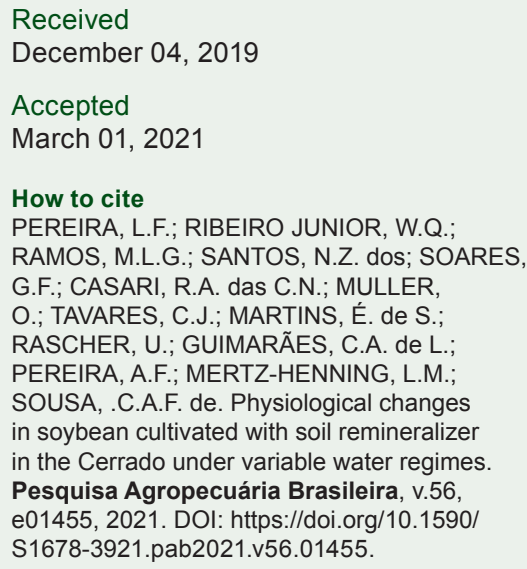

da idade fenológica da soja e do RH, mas não houve diferenças entre os três tratamentos em 2017 e 2018. A redução da produtividade da soja é atribuída ao fechamento estomático, à perda da capacidade fotoprotetora e aos danos ao maquinário fotossintético causados pela seca.

Termos para indexação: Glycine max, linha de aspersores, mica xisto, fotossíntese, estresse hídrico.

\section{Introduction}

In 2020, Brazil produced more than 124 million tons of soybean [Glycine max (L.) Merr.] and became the world's largest producer of this grain (Acompanhamento..., 2020). However, the expansion of soybean production to the Midwest of the country has caused some challenges, including rainfall scarcity and concentration (Cattelan \& Dall'Agnol, 2018). Although the crop is planted in the rainy season, dry spells may limit its productivity (Bornhofen et al., 2015).

Drought limits plant growth through reductions in cell expansion, but also severely interferes with carbon metabolism, particularly affecting photosynthesis (Baker, 2008). Under water deficit, plants suffer from severe photosynthetic limitation due to stomatal closure, which reduces the entry of $\mathrm{CO}_{2}$. Besides this reduction in carbon fixation, under drought excess, light energy that is not used by the Calvin cycle may induce the formation of reactive oxygen species that may, in turn, degrade important cell constituents such as membranes, proteins, and nucleic acids (Kar, 2011; Choudhury et al., 2017). Furthermore, drought may also influence the total duration of the crop cycle, shortening its vegetative and reproductive stages, directly affecting productivity. Even modest reductions in water availability can cause major impacts, including a soil water potential of $-0.8 \mathrm{MPa}$ and reductions in soybean leaf area and dry matter of 60 and $65 \%$, respectively, ultimately leading to decreased productivity (Board \& Kahlon, 2011).

For these reasons, new agricultural practices for retaining soil water that could benefit plant metabolism under stress conditions are being sought and evaluated. Among these practices, the use of rock powder has been shown to increase plant growth, leaf area index, and yield in maize (Zea mays L.) (Malekian et al., 2012) and also to improve nutrient supply and the complexation of heavy metals (Zhang, 2017).

The water retention capacity of a soil is directly linked to its clay content, which is responsible for the expansion and contraction effect in soils under hydric stress (Novák \& Hlaváčiková, 2019). Rock powder may decrease this stress by increasing resilience to drought in agricultural landscapes, specifically by improving soil moisture retention through high surface area minerals as zeolite and smectite, increasing the availability of drought protective elements to the plant through basalts, smectites, and zeolites added to soil water (Pratt et al., 2020). Therefore, in the presence of water, soils supplied with clay minerals from rocks may undergo changes in their physical properties, such as density, porosity, hydraulic conductivity, and water retention capacity (Winiwarter \& Blum, 2008). These changes may lead to physiological alterations in plants, including gas exchange and chlorophyll $a$ fluorescence (Baker, 2008; Marschner, 2012).

The addition of rock powder to Brazilian soils has been studied as a potential source of mineral phases and potassium using alkaline volcanic breccia, biotite shale, phlogopitite, and ultramafic alkaline rocks (Theodoro et al., 2006; Martins et al., 2010; Ribeiro et al., 2010; Souza et al., 2016). However, only the impact on plant nutrition has been evaluated, indicating the need for further researches on conditioning effects due to the retention of water by clay minerals.

The objective of this work was to evaluate the influence of the soil remineralizer fine-graded mica schist (FMS) on soybean physiology, productivity, and grain quality under different water regimes (WRs) in the Brazilian Cerrado. 


\section{Materials and Methods}

Two experiments were carried out in a no-tillage system under field conditions at Embrapa Cerrados, in Planaltina, Distrito Federal, Brazil $\left(15^{\circ} 35^{\prime} 30^{\prime \prime} \mathrm{S}\right.$, $\left.47^{\circ} 42^{\prime} 30^{\prime \prime} \mathrm{W}\right)$, from July to November 2017 and from June to October 2018. The region has an average annual rainfall of $1,500 \pm 500 \mathrm{~mm}$, and its prevailing climate is Aw, according to Köppen's classification, tropical, hot, and humid (Alvares et al., 2013), with two well-defined seasons: dry from May to September and humid from October to April. The climatic conditions during the two years of soybean cultivation are shown in Figure 1. Soybean was planted in the winter because there is no rainfall during this period, allowing a better control of the applied water levels. The used cultivar was NA 5909 RG from the super-early maturity group.
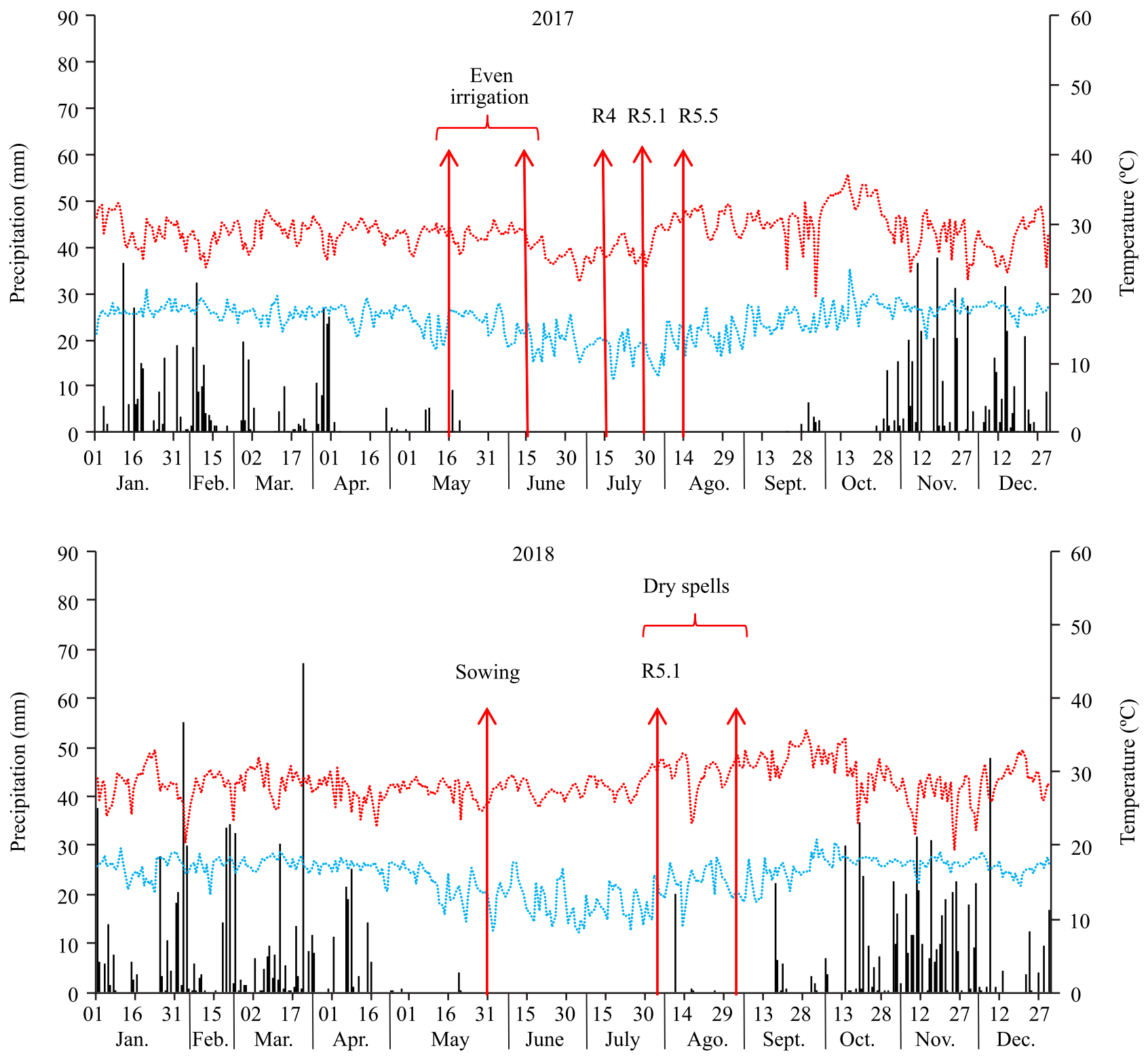

Precipitation

Maximum temperature

Minimum temperature

Figure 1. Precipitation and minimum and maximum temperatures in the experimental area in 2017 and 2018. R4, R5.1, and R5.5 represent soybean (Glycine max) phenological stages. 
According to the Brazilian Soil Classification System (Santos et al., 2018), the soil of the region is classified as a Latossolo Vermelho distrófico, i.e., a typical Oxisol (Burt, 2014). Soil analysis was performed in the $0-20 \mathrm{~cm}$ layer before the installation of the experiment in 2017 and in early 2019, in order to ensure that proper fertilization and water were the only limiting factors (Table 1). The experimental design was randomized complete blocks with four replicates in a split-plot arrangement, in which the main plot was composed of three treatments - fine-graded mica schist (FMS) as the soil remineralizer, $\mathrm{N}_{-} \mathrm{P}_{2} \mathrm{O}_{5^{-}}$ $\mathrm{K}_{2} \mathrm{O}$ fertilization, and control - and the subplots, of four water regimes (WRs). Each plot consisted of two central lines of $5 \mathrm{~m}$, eliminating $1.0 \mathrm{~m}$ of the border.

The used FMS is a biotite schist from the Neoproterozoic Araxá group in the state of Goiás, Brazil (Pimentel, 2016). According to Souza et al. (2016, 2017), the geochemical and mineralogical characterization of the biotite rock are: $70 \%$ plagioclase, $17 \%$ biotite, $7 \%$ garnet, $4 \%$ micro lithium, and quartz and calcite as accessory minerals. The geochemical composition is: $50.9 \% \mathrm{SiO}_{2}, 13.0 \% \mathrm{Al}_{2} \mathrm{O}_{3}, 8.6 \% \mathrm{Fe}_{2} \mathrm{O}_{3}$, 9.8\% $\mathrm{MgO}, 7.9 \% \mathrm{CaO}, 3.0 \% \mathrm{Na}_{2} \mathrm{O}, 2.2 \% \mathrm{~K}_{2} \mathrm{O}, 0.1 \%$ $\mathrm{P}_{2} \mathrm{O}_{5}, 0.2 \% \mathrm{MnO}, 3.2 \%$ volatile compounds $\left(\mathrm{CO}_{2}+\mathrm{SO}_{3}\right.$ $\left.+\mathrm{H}_{2} \mathrm{O}\right), 0.5 \%$ total carbon, and $0.1 \%$ sulfur.

In the first year, FMS was added to soil surface at a rate of $5 \mathrm{Mg} \mathrm{ha}^{-1}$, whereas, in the second, it was applied at $10 \mathrm{Mg} \mathrm{ha}^{-1}$ in the same plots. For the $\mathrm{N}-\mathrm{P}_{2} \mathrm{O}_{5}-\mathrm{K}_{2} \mathrm{O}$ (02-28-14) treatment, the applied fertilization rates were $6 \mathrm{~kg} \mathrm{ha}^{-1} \mathrm{~N}, 80 \mathrm{~kg} \mathrm{ha}^{-1} \mathrm{P}_{2} \mathrm{O}_{5}$, and $42 \mathrm{~kg} \mathrm{ha}^{-1} \mathrm{~K}_{2} \mathrm{O}$. In the control, no fertilization was performed.

In the second year, the FMS and $\mathrm{N}-\mathrm{P}_{2} \mathrm{O}_{5}-\mathrm{K}_{2} \mathrm{O}$ treatments received maintenance fertilization with $\mathrm{P}$ $\left(80 \mathrm{~kg} \mathrm{ha}^{-1} \mathrm{P}_{2} \mathrm{O}_{5}\right)$ as simple superphosphate $\left(20 \% \mathrm{P}_{2} \mathrm{O}_{5}\right)$, since the $\mathrm{K}$ contents were adequate. In both years, soybean seeds were inoculated with Bradyrhizobium japonicum (Kirchner 1896) Jordan 1982 (1x109 CFU $\mathrm{g}^{-1}$ inoculant) at $200 \mathrm{~g}$ per $50 \mathrm{~kg}$ seeds. From November 2017 to May 2018, millet (Pennisetum glaucum R.Br.) was used as a cover crop, with residual soybean fertilization.

In 2017 and 2018, irrigation was carried out during the morning, homogeneously for 35 days after emergence (DAE), using sprinklers with the same flow rate to determine irrigation time. After this period, the line source methodology was adopted (Hanks et al., 1976), modified by introducing an irrigation line (Jayme-Oliveira et al., 2017) with sprinklers with a decreasing flow from the middle to edge of the line, in order to produce a water deficit gradient. The WRs were obtained through the 36/42 irrigation sprinkler line, $20 \mathrm{~m}$ wide on each side, connected to the selfpropelled irrigation equipment, TurboMaq 75/GB (IrrigaBrasil, Pinhais, PR, Brazil), with adjustable speed according to the water depth to be applied.

The highest level of irrigation to be applied was determined according to the irrigation monitoring program of Embrapa Cerrados, based on the replacement of evapotranspiration (Embrapa, 2011), soil type, agrometeorological indicator of the region, and date of plant emergence, as well as time of irrigation and speed of the line, depending on water depth. Four irrigation levels were spread along the line, with different lengths from the initial portion of the system, representing the four WRs. During the uniform irrigation phase from July 27 to August 30, 2017, and from June 8 to July 13, 2018, approximately $160 \mathrm{~mm}$ water were supplied. The depths accumulated during the plant cycle from the central area to the edge of the

Table 1. Soil analysis after two years of implementation of the experiment at a depth of 0-20 cm in 2017 and 2019.

\begin{tabular}{|c|c|c|c|c|c|c|c|c|c|c|c|c|}
\hline Depth & $\begin{array}{c}\mathrm{pH} \\
\left(\mathrm{H}_{2} \mathrm{O}\right)\end{array}$ & $\begin{array}{c}\mathrm{OM} \\
\left(\mathrm{g} \mathrm{kg}^{-1}\right)\end{array}$ & $\mathrm{Ca}$ & $\mathrm{Mg}$ & $\begin{array}{c}\mathrm{Al} \\
\mathrm{mol}_{\mathrm{c}} \mathrm{dm}\end{array}$ & $\mathrm{H}+\mathrm{Al}$ & $\mathrm{K}$ & $\begin{array}{c}\mathrm{P} \\
\left(\mathrm{mg} \mathrm{L}^{-1}\right)\end{array}$ & \multicolumn{3}{|c|}{-----( $\left(\mathrm{cmol}_{\mathrm{c}} \mathrm{dm}^{-3}\right)^{-}$} & $\begin{array}{c}\mathrm{V} \\
(\%)\end{array}$ \\
\hline \multicolumn{13}{|l|}{2017} \\
\hline $0-20$ & 5.74 & 22.46 & 2.317 & 1.146 & 0.069 & 5.461 & 0.232 & 9.868 & 9.225 & 3.834 & 3.765 & 40.8 \\
\hline \multicolumn{13}{|l|}{2019} \\
\hline $\mathrm{WR} 1^{(1)}$ & 6.3 & 49.00 & 5.73 & 2.36 & 0.0 & 3.9 & 1.55 & 44.86 & 13.58 & 9.64 & 9.64 & 66 \\
\hline WR2 & 6.3 & 47.20 & 5.83 & 2.40 & 0.0 & 3.8 & 1.51 & 43.70 & 13.58 & 9.74 & 9.74 & 68 \\
\hline WR3 & 6.3 & 42.66 & 5.16 & 2.20 & 0.0 & 3.8 & 1.49 & 41.00 & 12.65 & 8.85 & 8.85 & 71 \\
\hline WR4 & 6.4 & 44.56 & 5.16 & 2.33 & 0.0 & 3.8 & 2.07 & 31.36 & 13.36 & 9.56 & 9.56 & 70 \\
\hline
\end{tabular}

${ }^{(1)} \mathrm{WR}$, water regime (WR1, WR2, WR3, and WR4 are equivalent to $100,65,44$, and $28 \%$ of crop evapotranspiration replacement, respectively). OM, organic matter; CEC, cation exchange capacity; SB, sum of bases; and V, base saturation. 
line, corresponding to WR1, WR2, WR3, and WR4, respectively, were: $634.35 \mathrm{~mm}(4 \mathrm{~m}), 420.55 \mathrm{~mm}(10 \mathrm{~m})$, $274.68 \mathrm{~mm}(13 \mathrm{~m})$, and $160.01 \mathrm{~mm}(16 \mathrm{~m})$ in 2017 ; and $531.43 \mathrm{~mm}$ (4 m), $343.15 \mathrm{~mm}$ (10 m), $237.45 \mathrm{~mm}(13 \mathrm{~m})$, and $164.79 \mathrm{~mm}(16 \mathrm{~m})$ in 2018; the numbers between parentheses represent the distance of each WR from the center to the edge of the irrigation line, and each WR was formed by overlapping sprinklers. Irrigation was performed according to the evapotranspiration of the crop, and WR1, WR2, WR3, and WR4 in 2017 and 2018 corresponded to a mean value of 100, 65, 44 , and $28 \%$ of crop evapotranspiration replacement, respectively.

In the experiment conducted in 2017, at 52, 62, and 76 DAE, leaf gas exchange and chlorophyll $a$ fluorescence were evaluated in the R4, R5.1, and R5.5 phenological stages, respectively. In the experiment carried out in 2018, assessments were made from 63 DAE in the R5.1 phenological stage. Leaf gas exchange, fluorescence, and vegetation indexes were obtained. From 63 DAE onwards, the simulation of a 15-day dry spell started. In the sixteenth and seventeenth days, irrigation was performed to replace the water lost by evapotranspiration. Gas exchange analysis was carried out on the first, eighth, fifteenth, and seventeenth day after irrigation suppression (DAIS). The operating efficiency of photosystem II (PSII) $\left(\mathrm{F}_{\mathrm{q}}{ }^{\prime} / \mathrm{F}_{\mathrm{m}}{ }^{\prime}\right)$ was measured using the light-induced fluorescence transient (LIFT) methodology (Pieruschka et al., 2014) through the LIFT-REM fluorometer (Soliense Inc., Shoreham, NY, USA), and vegetation indices were assessed using a spectrometer included in the same equipment to measure fluorescence. These evaluations were carried out during the initial ten days of the dry spell experiment.

The net assimilation of $\mathrm{CO}_{2}(A)$, stomatal conductance $\left(g_{\mathrm{s}}\right)$, and transpiration rate $(E)$ were evaluated from 9:00 a.m. to 1:00 p.m., under an irradiance of $1,200 \mu \mathrm{mol}$ photons $\mathrm{m}^{-2} \mathrm{~s}^{-1}$ and external $\mathrm{CO}_{2}$ concentration of $400 \mu \mathrm{mol} \mathrm{mol}^{-1}$ air. In 2017, the LI-6400XT portable open-flow gas exchange system (LI-COR Inc., Lincoln, NE, USA) was used; in 2018, the same variables were evaluated, but using another portable open-flow gas exchange system, the LCproSD (ADC Bioscientific Ltd., Herts, United Kingdom).

In 2017, chlorophyll $a$ fluorescence analyzes were performed using the fluorescence chamber coupled to the $\mathrm{CO}_{2}$ assimilation chamber of the LI-6400XT infrared gas analyzer. In each plot, to quantify gas exchange and chlorophyll $a$ fluorescence, three evaluations were carried out on the central leaf of the fully-expanded trifolium of physiologically mature soybean light-adapted leaves.

The effective quantum efficiency of photosystem II (Genty et al., 1989) was calculated using the formula: $\mathrm{F}_{\mathrm{v}}{ }^{\prime} / \mathrm{F}_{\mathrm{m}}{ }^{\prime}=\left(\mathrm{F}_{\mathrm{m}}{ }^{\prime}-\mathrm{F}_{0}{ }^{\prime}\right) / \mathrm{F}_{\mathrm{m}}{ }^{\prime}$. The electron transport ratio (ETR) (Baker, 2008) was obtained by: $\mathrm{ETR}=\phi \mathrm{PSII} \times \mathrm{DFF} \times(0.84) \times(0.5)$, where $\mathrm{DFF}$ is the photon flow density or the amount of light absorbed ( $\mu \mathrm{m}$ photons $\mathrm{m}^{-2} \mathrm{~s}^{-1}$ ) (Baker, 2008).

The STS-VIS spectrometer (Ocean Optics, Inc., Largo, FL, USA), installed in the LIFT equipment with a spectral range of $400-800 \mathrm{~nm}$, was used to determine the vegetation indices photochemical reflectance index (PRI) and normalized difference vegetation index (NDVI). These spectral indices were calculated as follows: NDVI $=\left(\mathrm{R}_{800}-\mathrm{R}_{640}\right) /\left(\mathrm{R}_{800}+\mathrm{R}_{640}\right)$, and PRI $=\left(R_{531}-R_{570}\right) /\left(R_{531}+R_{570}\right)$. Poor signal-to-noise ratio data were eliminated.

Yield was determined after correction of grain humidity to $13 \%$ (w/w). In 2017, grain quality (protein and oil contents) was analyzed, together with plant height, number of pods, number of internodes, stem diameter, and thousand-grain weight (TGW).

All data were subjected to Shapiro-Wilk's normality test. The analysis of variance was performed, and means were compared by Tukey's test, at 5\% probability, using the SAS statistical software, version 9.1.2 (SAS Institute, Inc., Cary, NC, USA). The statistical model was adjusted with SAS PROC MIXED, using the method of restricted maximum likelihood.

\section{Results and Discussion}

In 2017, there were no statistical differences for physiological evaluations and yield between the FMS, $\mathrm{N}-\mathrm{P}_{2} \mathrm{O}_{5}-\mathrm{K}_{2} \mathrm{O}$, and control treatments within each WR for each soybean phenological stage (Tables 2 and 3). In the first year of remineralizer application, it was anticipated that, due to the short time allowed for reaction and to the chemical attack by microorganisms and the rhizosphere, there would be no effect (Harley \& Gilkes, 2000). Indeed, only the effects of WR and phenological stage were observed, as all the studied variables presented significant alterations, with greater effects as the WR was reduced and when the 
crop progressed in its phenological stage, especially in R5.5 and under severe water stress (Table 3). Furthermore, during the first year of the experiment, significant reductions in $A, g_{\mathrm{s}}$, and $E$ occurred in function of the WR and phenological stage. Therefore, in addition to limiting $\mathrm{CO}_{2}$ entry, stomatal closure led to a state of over excitation of the thylakoid membranes in the chloroplasts (Baker, 2008). Therefore, with an increased time of exposure to drought, the damage becomes more severe, as shown by the reductions in $\mathrm{F}_{\mathrm{v}}{ }^{\prime} / \mathrm{F}_{\mathrm{m}},{ }_{\mathrm{FSII}}$, and ETR, limiting the photosynthetic potential of soybean (Baker, 2008).

Drought accelerates the production of abscisic acid and ethylene, which are directly related to abortion, early senescence of leaves, and reduction of gas exchange, culminating in the early maturation of grains and reduced productivity (Kar, 2011), symptoms which were also detected in the present study. The influence of drought on the photosynthetic metabolism of soybean was very clear, since the early effect of the WR was already significant in the R4 stage in WR4 (Table 3). In the other stages, such as R5.1 and R5.4, the reductions in $\mathrm{F}_{\mathrm{v}}{ }^{\prime} / \mathrm{F}_{\mathrm{m}}{ }^{\prime}, \phi_{\mathrm{FSII}}$, and ETR were drastic. Under severe drought, the super excitation in the thylakoid membranes leads to damage to plant tissues, much of which is irreversible, which may explain the reduction in $A$ (Table 3), as also observed by DaMatta et al. (2018). Such damage to plant metabolism is even more harmful during the reproductive stage (Board \& Kahlon, 2011), as soybean depends on photoassimilate production for maximum productivity. Therefore, progressive drought also caused a progressive reduction in gas exchange during the R4, R5.1, and R5.5 stages (Figure 2) due to photosynthetic machinery damage and plant metabolism effects. These results are in agreement with the reduction in productivity in the 2017 harvest, which shows the cause-and-effect relationship of the influence of drought on soybean physiological parameters, justifying reductions in crop yield (Table 2).

It was anticipated that the FMS treatment might alleviate the deleterious effects of drought on plant physiology during the second year of application considering the potential benefits of the rainy period during the summer. However, in 2018, there were no statistically significant differences between the FMS, N- $\mathrm{P}_{2} \mathrm{O}_{5}-\mathrm{K}_{2} \mathrm{O}$, and control treatments for $A, g_{s}$, and $E$ (Table 4).

When comparing different WRs, the treatments that received most water (WR1 and WR2) were statistically similar, while the least irrigated (WR3 and WR4) had significantly lower values for the evaluated parameters, with WR4 presenting the lowest values for all days after irrigation suppression. On the eighth DAIS, the symptoms of the dry spells were identified in almost all WRs except in WR1, and, on the fifteenth DAIS, there were no statistical differences between the WRs. However, after irrigation on the seventeenth DAIS, WR1 and WR2 showed higher values for $A, g_{\mathrm{s}}$ and $E$ (Table 4). Therefore, the assessed physiological variables decline rapidly according to the duration of the drought period when there was a simulation of dry spells, and, on the fifteenth DAIS, reductions of up to $60 \%$ were observed.

Table 2. Productivity of soybean (Glycine max) in the 2017 and 2018 cropping seasons under four water regimes and three fertilization treatments ${ }^{(1)}$.

\begin{tabular}{|c|c|c|c|c|c|c|}
\hline \multirow{2}{*}{$\begin{array}{l}\text { Water regime } \\
\text { (WR) }\end{array}$} & \multicolumn{3}{|c|}{ Productivity $\left(\mathrm{kg} \mathrm{ha}^{-1}\right)-2017$ cropping season } & \multicolumn{3}{|c|}{ Productivity $\left(\mathrm{kg} \mathrm{ha}^{-1}\right)-2018$ cropping season } \\
\hline & FMS & $\mathrm{N}-\mathrm{P}_{2} \mathrm{O}_{5}-\mathrm{K}_{2} \mathrm{O}$ & Control & FMS & $\mathrm{N}-\mathrm{P}_{2} \mathrm{O}_{5}-\mathrm{K}_{2} \mathrm{O}$ & Control \\
\hline WR1 & $3,524 \mathrm{Aa}$ & $3,835 \mathrm{Aa}$ & $3,852 \mathrm{Aa}$ & $4,208 \mathrm{Aa}$ & $4,425 \mathrm{Aa}$ & $4,514 \mathrm{Aa}$ \\
\hline WR2 & $4,063 \mathrm{Aa}$ & $4,136 \mathrm{Aa}$ & $3,114 \mathrm{Ab}$ & $3,539 \mathrm{Ba}$ & $4,034 \mathrm{Ba}$ & $3,723 \mathrm{Ba}$ \\
\hline WR3 & $1,544 \mathrm{Ba}$ & $1,610 \mathrm{Ba}$ & $1,697 \mathrm{Ba}$ & $2,741 \mathrm{Ca}$ & $2,569 \mathrm{Ca}$ & $2,639 \mathrm{Ca}$ \\
\hline WR4 & $1,007 \mathrm{Ba}$ & $1,421 \mathrm{Ba}$ & $998 \mathrm{Ba}$ & $1,990 \mathrm{Da}$ & $1,930 \mathrm{Da}$ & $1,985 \mathrm{Da}$ \\
\hline CV1 $(\%)$ & & 17.8 & & & 10.7 & \\
\hline CV2 $(\%)$ & & 16.1 & & & 11.5 & \\
\hline
\end{tabular}

(1)Means followed by equal letters, lowercase in the lines comparing treatments (FMS, $\mathrm{N}-\mathrm{P}_{2} \mathrm{O}_{5}-\mathrm{K}_{2} \mathrm{O}$, and control) and uppercase in the columns comparing WRs, do not differ by Tukey's test, at 5\% probability. WR1, WR2, WR3, and WR4, equivalent to 100, 65, 44, and $28 \%$ of crop evapotranspiration replacement, respectively. CV1, coefficient of variation related to treatments; and CV2, coefficient of variation related to WRs. FMS, fine-graded mica schist. 
After irrigation on the sixteenth and seventeenth DAIS, there was only a significant response for WR1 and WR2, with a tendency to recover plant photosynthetic capacity, with a higher $A, g_{s}$, and $E$ (Table 4). However, in WR3 and WR4, there was no recovery of photosynthetic performance. It is possible that drought, during the reproductive stage, led to an accelerated leaf senescence and a reduced crop cycle, so that, even after re-irrigation, these WRs did not recover (Menezes-Silva et al., 2017). Therefore, stress due to dry spells causes modifications in the metabolism of plants, leading to the shortening of their cycle. In this case, the use of FMS was unable to ameliorate this response (Baker, 2008). FMS, N-P $\mathrm{O}_{5} \mathrm{O}^{-}$ $\mathrm{K}_{2} \mathrm{O}$, and the control behaved similarly in terms of NDVI and PRI, measured using the spectrometer, and $\mathrm{F}_{\mathrm{q}}{ }^{\prime} / \mathrm{F}_{\mathrm{m}}$ ', using the LIFT methodology, in 2018. The imposition of simulated dry spells caused a gradual

Table 3. Net photosynthesis $(A)$, stomatal conductance $\left(g_{\mathrm{s}}\right)$, internal $\mathrm{CO}_{2}$ concentration, and transpiration rate $(E)$, as well as effective quantum yield ( $\left.{ }^{\mathrm{F} S \mathrm{SII}}\right)$ of photosystem two $\left(\mathrm{F}_{\mathrm{v}}{ }^{\prime} / \mathrm{F}_{\mathrm{m}}{ }^{\prime}\right)$ and electron transport rate $(\mathrm{ETR})$, in three phenological stages (R4, R5.1, and R5.5) of soybean (Glycine max) under four water regimes (WR1, WR2, WR3, and WR4) in three treatments (fine-graded mica schist, $\mathrm{N}-\mathrm{P}_{2} \mathrm{O}_{5}-\mathrm{K}_{2} \mathrm{O}$, and control), in the winter of $2017^{(1)}$.

\begin{tabular}{|c|c|c|c|c|c|c|c|c|c|c|c|c|c|}
\hline \multirow[t]{2}{*}{ Variable } & \multicolumn{3}{|c|}{ WR1 } & \multicolumn{3}{|c|}{ WR2 } & \multicolumn{3}{|c|}{ WR3 } & \multicolumn{3}{|c|}{ WR4 } & \multirow{2}{*}{$\begin{array}{c}\mathrm{CV} 1 / \mathrm{CV} 2 \\
(\%)\end{array}$} \\
\hline & FMS $^{(2)}$ & $\mathrm{N}-\mathrm{P}-\mathrm{K}^{(3)}$ & Control & FMS & N-P-K & Control & FMS & N-P-K & Control & FMS & N-P-K & Control & \\
\hline \multicolumn{14}{|c|}{ R4 phenological stage } \\
\hline$A$ & $19.33 \mathrm{Aa}$ & $20.60 \mathrm{Aa}$ & $19.96 \mathrm{Aa}$ & $20.26 \mathrm{Aa}$ & $20.55 \mathrm{Aa}$ & $20.22 \mathrm{Aa}$ & $20.18 \mathrm{Aa}$ & $21.56 \mathrm{Aa}$ & $19.26 \mathrm{Aa}$ & $13.81 \mathrm{Ba}$ & $13.44 \mathrm{Ba}$ & $14.73 \mathrm{Ba}$ & $7.8 / 7.4$ \\
\hline$g_{\mathrm{s}}$ & $0.31 \mathrm{Aa}$ & $0.32 \mathrm{Aa}$ & $0.31 \mathrm{Aa}$ & $0.31 \mathrm{Aa}$ & $0.33 \mathrm{Aa}$ & $0.29 \mathrm{Aa}$ & $0.29 \mathrm{Aa}$ & $0.31 \mathrm{Aa}$ & $0.30 \mathrm{Aa}$ & $0.15 \mathrm{Ba}$ & $0.14 \mathrm{Ba}$ & $0.16 \mathrm{Ba}$ & $14.8 / 17.6$ \\
\hline $\mathrm{C}_{\mathrm{i}}$ & $271 \mathrm{Aa}$ & $267 \mathrm{Aa}$ & $267 \mathrm{Aa}$ & 259Aa & $269 \mathrm{Aa}$ & $258 \mathrm{Aa}$ & $256 \mathrm{Aa}$ & $252 \mathrm{Aa}$ & $252 \mathrm{Aa}$ & $218 \mathrm{Ba}$ & $221 \mathrm{Ba}$ & $223 \mathrm{Ba}$ & $4.5 / 6$ \\
\hline$E$ & $4.93 \mathrm{Aa}$ & $5.56 \mathrm{Aa}$ & $5.14 \mathrm{Aa}$ & $5.07 \mathrm{Aa}$ & $5.39 \mathrm{Aa}$ & $4.92 \mathrm{Aa}$ & $4.73 \mathrm{Aa}$ & $5.15 \mathrm{Aa}$ & $5.15 \mathrm{Aa}$ & $3.32 \mathrm{Ba}$ & $2.91 \mathrm{Ba}$ & $3.44 \mathrm{Ba}$ & $9.5 / 13$ \\
\hline $\mathrm{F}_{\mathrm{v}}, \mathrm{F}_{\mathrm{m}}$ & $0.48 \mathrm{Aa}$ & $0.49 \mathrm{Aa}$ & $0.49 \mathrm{Aa}$ & $0.47 \mathrm{Aa}$ & 0.49 Aa & $0.51 \mathrm{Aa}$ & $0.51 \mathrm{Aa}$ & $0.51 \mathrm{Aa}$ & $0.48 \mathrm{Aa}$ & $0.48 \mathrm{Aa}$ & $0.51 \mathrm{Aa}$ & $0.50 \mathrm{Aa}$ & $5.4 / 5.4$ \\
\hline$\phi \mathrm{FSII}$ & $0.24 \mathrm{Aa}$ & $0.26 \mathrm{Aa}$ & $0.26 \mathrm{Aa}$ & $0.27 \mathrm{Aa}$ & $0.25 \mathrm{Aa}$ & 0.26 & $0.25 \mathrm{Aa}$ & $0.25 \mathrm{Aa}$ & $0.25 \mathrm{Aa}$ & $0.21 \mathrm{Ba}$ & $0.20 \mathrm{Ba}$ & $0.21 \mathrm{Ba}$ & $7.4 / 9.1$ \\
\hline ETR & $118 \mathrm{Aa}$ & $134 \mathrm{Aa}$ & $137 \mathrm{Aa}$ & $140 \mathrm{Aa}$ & $133 \mathrm{Aa}$ & $135 \mathrm{Aa}$ & $130 \mathrm{Aa}$ & 131Aa & $129 \mathrm{Aa}$ & $111 \mathrm{Ba}$ & $98 \mathrm{Ba}$ & $108 \mathrm{Ba}$ & $10.6 / 11.4$ \\
\hline \multicolumn{14}{|c|}{ R5.1 phenological stage } \\
\hline$A$ & $17.40 \mathrm{Aa}$ & $18.40 \mathrm{Aa}$ & $17.75 \mathrm{Aa}$ & $18.16 \mathrm{Aa}$ & $19.33 \mathrm{Aa}$ & $17.75 \mathrm{Aa}$ & $14.51 \mathrm{Ba}$ & $14.01 \mathrm{Ba}$ & $14.67 \mathrm{Ba}$ & $6.77 \mathrm{Ca}$ & $7.06 \mathrm{Ca}$ & $8.06 \mathrm{Ca}$ & $14.9 / 12.4$ \\
\hline$g_{\mathrm{s}}$ & $0.25 \mathrm{Ab}$ & $0.33 \mathrm{Aa}$ & $0.26 \mathrm{Ab}$ & $0.27 \mathrm{Aa}$ & $0.25 \mathrm{Aa}$ & $0.25 \mathrm{Aa}$ & $0.17 \mathrm{Ba}$ & $0.17 \mathrm{Ba}$ & $0.18 \mathrm{Ba}$ & $0.09 \mathrm{Ca}$ & $0.09 \mathrm{Ca}$ & $0.11 \mathrm{Ca}$ & $16.1 / 13.7$ \\
\hline $\mathrm{C}_{\mathrm{i}}$ & $255 \mathrm{Aa}$ & $280 \mathrm{Aa}$ & 261Aa & $263 \mathrm{ABa}$ & $244 \mathrm{ABa}$ & $255 \mathrm{Aba}$ & 237Aba & $235 \mathrm{ABa}$ & $243 \mathrm{Aba}$ & $258 \mathrm{Ba}$ & $251 \mathrm{Ba}$ & $249 \mathrm{Ba}$ & $5.9 / 5.6$ \\
\hline$E$ & $6.58 \mathrm{Aa}$ & 7.42Aa & $6.73 \mathrm{Aa}$ & $6.94 \mathrm{Aa}$ & $6.16 \mathrm{Aa}$ & $6.76 \mathrm{Aa}$ & $5.06 \mathrm{Ba}$ & $5.17 \mathrm{Ba}$ & $5.18 \mathrm{Ba}$ & $2.99 \mathrm{Ca}$ & $3.22 \mathrm{Ca}$ & $3.86 \mathrm{Ca}$ & $14.0 / 10.6$ \\
\hline $\mathrm{F}_{\mathrm{v}}, / \mathrm{F}_{\mathrm{m}}$ & $0.53 \mathrm{Aa}$ & $0.54 \mathrm{Aa}$ & $0.53 \mathrm{Aa}$ & $0.54 \mathrm{Ab}$ & $0.53 \mathrm{Ab}$ & $0.55 \mathrm{Aa}$ & $0.53 \mathrm{Ab}$ & $0.54 \mathrm{Ab}$ & $0.55 \mathrm{Aa}$ & $0.43 \mathrm{Ab}$ & $0.45 \mathrm{Ab}$ & $0.51 \mathrm{Aa}$ & $2.4 / 5.4$ \\
\hline$\phi \mathrm{FSII}$ & $0.30 \mathrm{ABa}$ & $0.28 \mathrm{Aba}$ & $0.31 \mathrm{ABa}$ & $0.31 \mathrm{Aa}$ & $0.31 \mathrm{Aa}$ & $0.32 \mathrm{Aa}$ & $0.28 \mathrm{Ba}$ & $0.27 \mathrm{Ba}$ & $0.27 \mathrm{Ba}$ & $0.15 \mathrm{Ca}$ & $0.16 \mathrm{Ca}$ & $0.16 \mathrm{Ca}$ & $5.6 / 9.9$ \\
\hline ETR & $154 \mathrm{ABa}$ & $147 \mathrm{Aba}$ & $161 \mathrm{ABa}$ & $166 \mathrm{Aa}$ & $162 \mathrm{Aa}$ & $169 \mathrm{Aa}$ & 146Ba & $141 \mathrm{Ba}$ & $143 \mathrm{Ba}$ & $79 \mathrm{Ca}$ & $81 \mathrm{Ca}$ & $99 \mathrm{Ca}$ & $6.3 / 11.5$ \\
\hline \multicolumn{14}{|c|}{ R5.4 phenological stage } \\
\hline$A$ & $17.5 \mathrm{Aa}$ & $17.22 \mathrm{Aa}$ & $16.56 \mathrm{Aa}$ & $14.43 \mathrm{Ba}$ & $14.42 \mathrm{Ba}$ & $12.58 \mathrm{Ba}$ & $9.16 \mathrm{Ca}$ & $10.03 \mathrm{Ca}$ & $9.67 \mathrm{Ca}$ & $4.26 \mathrm{Da}$ & $5.29 \mathrm{Da}$ & $7.73 \mathrm{Da}$ & $17.0 / 18.9$ \\
\hline$g_{\mathrm{s}}$ & $0.25 \mathrm{Aa}$ & $0.27 \mathrm{Aa}$ & $0.22 \mathrm{Aa}$ & $0.18 \mathrm{Ba}$ & $0.17 \mathrm{Ba}$ & $0.15 \mathrm{Ba}$ & $0.12 \mathrm{Ca}$ & $0.12 \mathrm{Ca}$ & $0.13 \mathrm{Ca}$ & $0.09 \mathrm{Ca}$ & $0.07 \mathrm{Ca}$ & $0.11 \mathrm{Ca}$ & $19.7 / 20.1$ \\
\hline $\mathrm{C}_{\mathrm{i}}$ & $255 \mathrm{Aab}$ & $263 \mathrm{Aa}$ & $249 b$ & $240 \mathrm{Aa}$ & $237 \mathrm{Aab}$ & $228 \mathrm{Ab}$ & 249Aa & $235 \mathrm{Ab}$ & $250 \mathrm{Aa}$ & 299Aa & $267 \mathrm{Aab}$ & $259 \mathrm{Ab}$ & $3.0 / 9.0$ \\
\hline$E$ & $6.07 \mathrm{Aa}$ & 7.59Aa & $6.34 \mathrm{Aa}$ & $5.34 \mathrm{Ba}$ & $5.12 \mathrm{Ba}$ & $4.78 \mathrm{Ba}$ & $3.63 \mathrm{BCa}$ & $4.18 \mathrm{BCa}$ & $4.27 \mathrm{BCa}$ & $2.97 \mathrm{Ca}$ & $2.76 \mathrm{Ca}$ & $3.74 \mathrm{Ca}$ & $19.5 / 21.2$ \\
\hline $\mathrm{F}_{\mathrm{v}}{ }^{\prime} / \mathrm{F}_{\mathrm{m}}$, & $0.54 \mathrm{Aa}$ & $0.54 \mathrm{Aa}$ & $0.55 \mathrm{Aa}$ & $0.52 \mathrm{ABa}$ & $0.53 \mathrm{ABa}$ & $0.49 \mathrm{Aba}$ & $0.44 \mathrm{Ba}$ & $0.47 \mathrm{Ba}$ & $0.50 \mathrm{Ba}$ & $0.31 \mathrm{Ca}$ & $0.35 \mathrm{Ca}$ & $0.45 \mathrm{Ca}$ & $9.8 / 10.8$ \\
\hline$\phi \mathrm{FSII}$ & $0.28 \mathrm{Aa}$ & $0.29 \mathrm{Aa}$ & $0.32 \mathrm{Aa}$ & $0.28 \mathrm{Aa}$ & $0.27 \mathrm{Aa}$ & $0.28 \mathrm{Aa}$ & $0.18 \mathrm{Ba}$ & $0.22 \mathrm{Ba}$ & $0.20 \mathrm{Ba}$ & $0.09 \mathrm{Ca}$ & $0.13 \mathrm{Ca}$ & $0.16 \mathrm{Ca}$ & $20.9 / 18.6$ \\
\hline ETR & $147 \mathrm{Aa}$ & $156 \mathrm{Aa}$ & $167 \mathrm{Aa}$ & $145 \mathrm{Aa}$ & $142 \mathrm{Aa}$ & 144Aa & $94 \mathrm{Ba}$ & $115 \mathrm{Ba}$ & $106 \mathrm{Ba}$ & $48.39 \mathrm{Ca}$ & $69.86 \mathrm{Ca}$ & $83.31 \mathrm{Ca}$ & $21.7 / 18.6$ \\
\hline
\end{tabular}

(1)Means followed by equal letters, lowercase in the lines comparing treatments within each WR and uppercase comparing each conditioner in the WRs within each phenological stage, do not differ by Tukey's test, at $5 \%$ probability. ${ }^{(2)}$ Fine-graded mica schist. ${ }^{(3)} \mathrm{N}-\mathrm{P}_{2} \mathrm{O}_{5}-\mathrm{K}_{2} \mathrm{O}$ fertilization. WR1, WR2, WR3, and WR4, equivalent to $100,65,44$, and $28 \%$ of crop evapotranspiration replacement, respectively. CV1, coefficient of variation related to treatments; and CV2, coefficient of variation related to water regimes. 
reduction in these variables; however, the greatest differences were observed only in WR4 on the last day of evaluation (Figure 2).

NDVI measurements showed that drought accelerated pigment degradation processes, such as those of chlorophylls, and reduced vegetation density, which was more intense under severe water deficit (Figure 2) as found by Babar et al. (2006). A reduction in Fq'/Fm' was observed during drought imposition for all WRs. These results are indicative that all WRs were affected by the dry spells, such that the functioning of the photosystem reaction centers was impaired and ultimately biomass accumulation was reduced, as shown by the reductions in productivity (Cabrera-Bosquet et al., 2012; Pieruschka et al., 2014).

When the reaction centers of photosystem II remain open and linear electron transport is maintained, $\mathrm{F}_{\mathrm{q}}$ ' $\mathrm{F}_{\mathrm{m}}$ ' remains high. Otherwise, the reflections of such damage directly affect $\mathrm{F}_{\mathrm{q}}{ }^{\prime} / \mathrm{F}_{\mathrm{m}}{ }^{\prime}, A$, and, consequently, productivity (Figure 2 and Table 2). Regardless of whether the remineralizer was supplied, there was a strong reduction in absorption capacity and transformation of light energy into carbohydrates, since the reaction centers of photosystem II remained closed, resulting in metabolic damage, especially on the last day of evaluation for the FMS, N- $\mathrm{P}_{2} \mathrm{O}_{5}-\mathrm{K}_{2} \mathrm{O}$, and control treatments (Baker et al., 2008). Moreover,
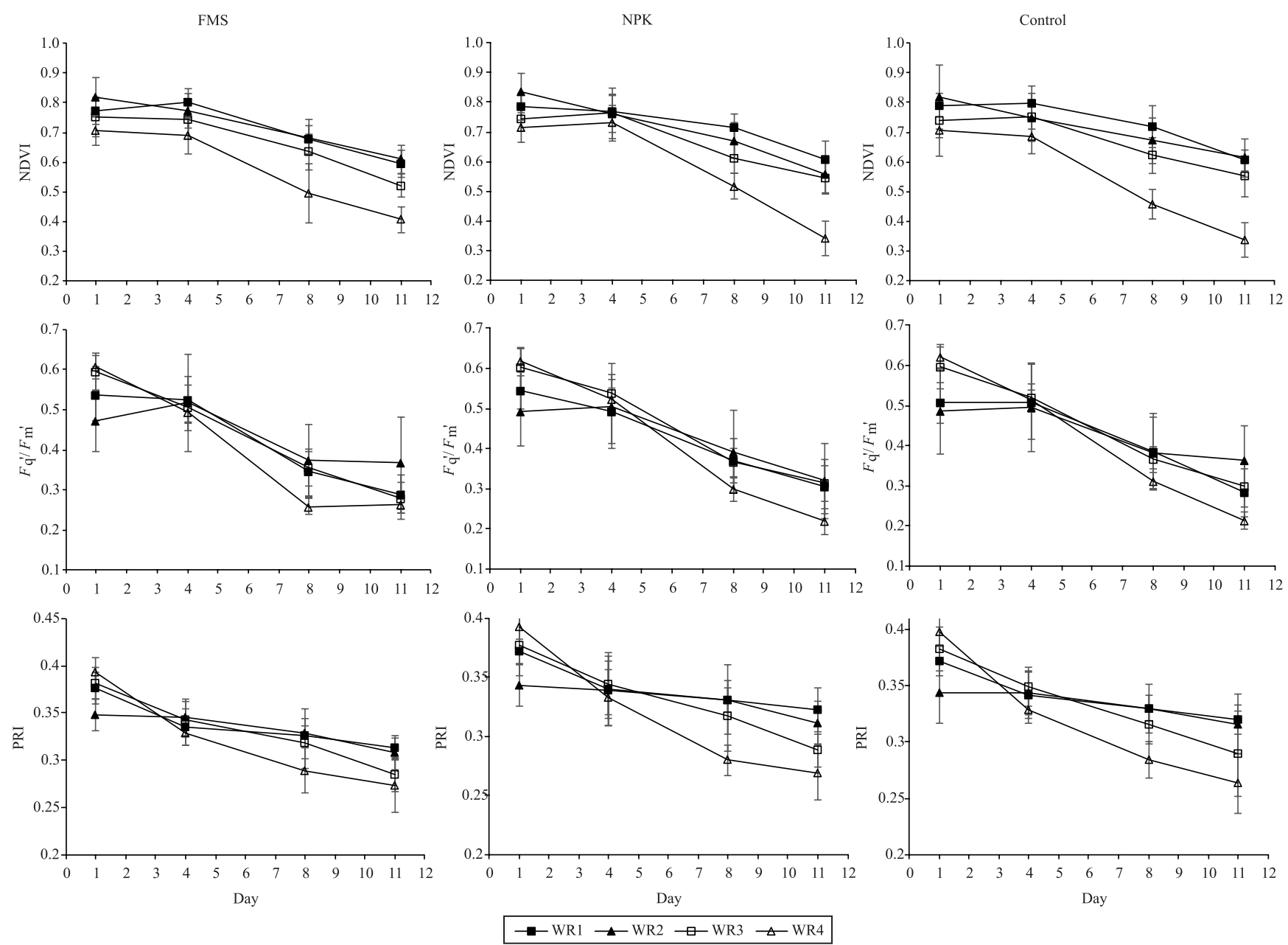

Figure 2. Normalized difference vegetation index (NDVI), effective quantum yield of photosystem two $\left(\mathrm{F}_{\mathrm{q}}{ }^{\prime} / \mathrm{F}_{\mathrm{m}}{ }^{\prime}\right)$, and reflectance photochemical index (PRI) for the fine-graded mica shist (FMS), $\mathrm{N}-\mathrm{P}_{2} \mathrm{O}_{5}-\mathrm{K}_{2} \mathrm{O}$, and control treatments evaluated during ten days of water deficit in the winter of 2018. 


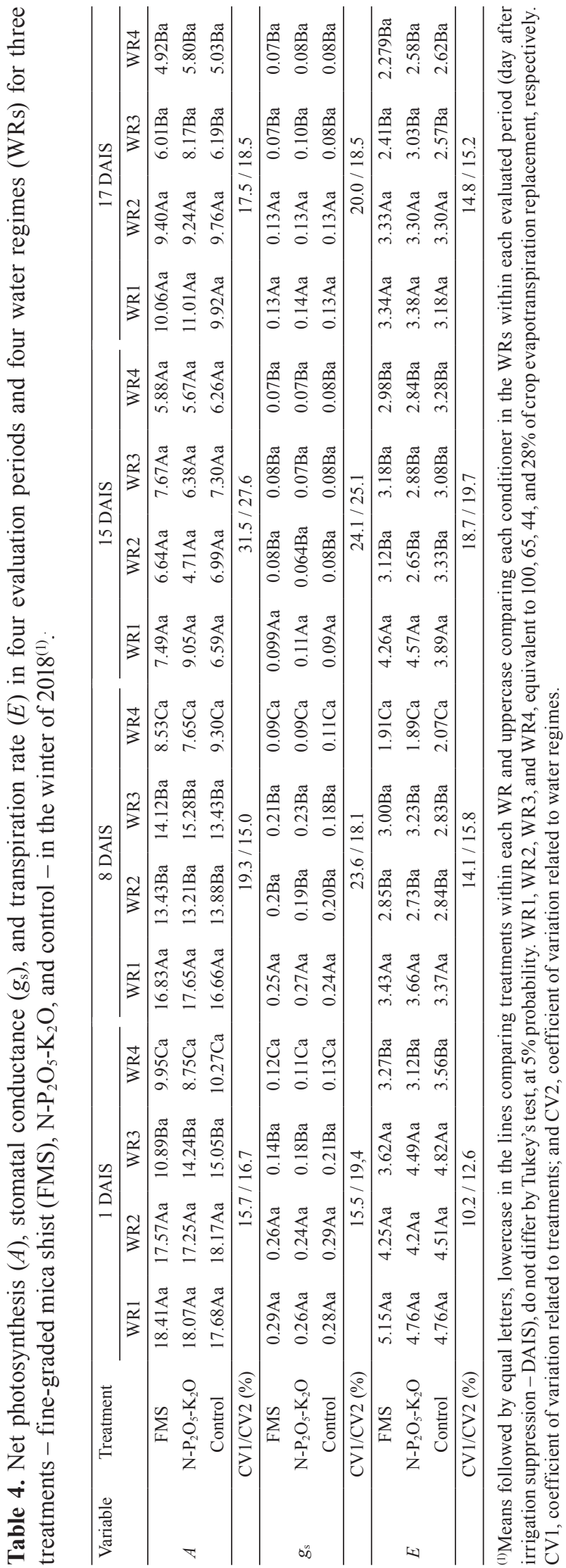

dry spells caused an increase in the ability of soybean to dissipate the excess excitation energy from the thylakoid membranes through the xanthophyll cycle, due to observed reductions in PRI (Figure 2), which may be closely related to the ability to maintain photosynthetic metabolism during drought (Gamon et al., 1997; El-Hendawy et al., 2015; Elsayed \& Darwish, 2017).

Productivity was only affected in the control treatment in 2017 in WR2, which did not happen in 2018 , since all treatments were statistically similar in this year (Table 2). In the second year, there was no statistical difference between FMS, N- $\mathrm{P}_{2} \mathrm{O}_{5}-\mathrm{K}_{2} \mathrm{O}$, and the control for any of the WRs studied. The production components only differed from WR (Table 5). It should be noted that the entire experimental area had been regularly fertilized overtime to eliminate the influence of nutritional factors so that the soybean plants were only affected by the manipulation of water levels. Therefore, due to the nutritional residue of previous harvests, high yields (Malekian et al., 2012; Li et al., 2014), including for the control treatment, were also observed (Table 2).

Protein and oil contents in the grains were not affected by the treatments and only responded to the applied WR (Figure 3). Protein content was higher in the less irrigated WRs, i.e., in WR3 and WR4, and oil percentage was lower. This is a commonly observed effect of drought as the greater amount of water in the irrigated treatments stimulates oil production and dilutes the protein content of grains (Ghassemi-Golezani \& Lotfi, 2013). Therefore, there is an antagonistic relationship between protein and oil content regarding drought since this stress has negative effects on plant primary metabolism and, consequently, on lipid biosynthesis, which can lead to lower lipidic levels in drought situations (Figure 3).

Since the experiments were carried out over two harvests (2017 and 2018) and also without incorporation into the soil profile, the obtained results do not rule out a potential positive impact of the soil remineralizer throughout a longer period. Therefore, further longterm experiments with more years and remineralizer incorporation will be needed to test the hypothesis that this product retains water in the soil. Physical, chemical, and biological impacts may have occurred but have not yet been sufficient to impact productivity over the two experimental years. 
Table 5. Height $(\mathrm{H})$, pod number $(\mathrm{PN})$, number of internodes (NI), diameter (D), thousand-grain weight (TGW), and productivity of soybean (Glycine max) subjected to water deficit under the control, fine-graded mica shist (FMS), and $\mathrm{N}-\mathrm{P}_{2} \mathrm{O}_{5}-\mathrm{K}_{2} \mathrm{O}$ treatments in 2017.

\begin{tabular}{|c|c|c|c|c|c|c|}
\hline Variable & Treatment & WR1 & WR2 & WR3 & WR4 & CV1 / CV2 (\%) \\
\hline \multirow{3}{*}{$\mathrm{H}$} & FMS & $64.00 \mathrm{Ab}$ & $70.87 \mathrm{Ba}$ & $58.85 \mathrm{Ba}$ & $51.17 \mathrm{Cb}$ & \multirow{3}{*}{$5.84 / 3.74$} \\
\hline & $\mathrm{N}-\mathrm{P}_{2} \mathrm{O}_{5}-\mathrm{K}_{2} \mathrm{O}$ & 69.97Aa & $69.52 \mathrm{Aa}$ & $57.87 \mathrm{Ba}$ & $57.11 \mathrm{Ba}$ & \\
\hline & Control & 66.30Aab & $68 \mathrm{Aa}$ & $59.52 \mathrm{Ba}$ & $51.62 \mathrm{Cb}$ & \\
\hline \multirow{3}{*}{ PN } & FMS & $40.55 \mathrm{Aa}$ & $39.12 \mathrm{Aa}$ & $27.15 \mathrm{Ba}$ & $20.01 \mathrm{Ba}$ & \multirow{3}{*}{$23.61 / 21.02$} \\
\hline & $\mathrm{N}-\mathrm{P}_{2} \mathrm{O}_{5}-\mathrm{K}_{2} \mathrm{O}$ & $36.20 \mathrm{Aa}$ & $38.17 \mathrm{Aa}$ & $27.45 \mathrm{Ba}$ & $20.04 \mathrm{Ba}$ & \\
\hline & Control & 43.8Aa & $37.97 \mathrm{Aa}$ & $30.02 \mathrm{Ba}$ & $18.75 \mathrm{Ba}$ & \\
\hline \multirow{3}{*}{ NI } & FMS & $14.62 \mathrm{Aa}$ & $15.00 \mathrm{ABa}$ & $13.7 \mathrm{Ba}$ & $11.98 \mathrm{Ca}$ & \multirow{3}{*}{$6.24 / 5.37$} \\
\hline & $\mathrm{N}-\mathrm{P}_{2} \mathrm{O}_{5}-\mathrm{K}_{2} \mathrm{O}$ & $14.45 \mathrm{Aa}$ & $14.8 \mathrm{ABa}$ & $13.2 \mathrm{Ba}$ & $12.20 \mathrm{Ca}$ & \\
\hline & Control & $14.70 \mathrm{Aa}$ & $14.60 \mathrm{ABa}$ & $13.85 \mathrm{Ba}$ & $11.85 \mathrm{Ca}$ & \\
\hline \multirow{3}{*}{$\mathrm{D}$} & FMS & $5.95 \mathrm{Aa}$ & $6.58 \mathrm{ABa}$ & $5.72 \mathrm{Ba}$ & $5.53 \mathrm{Ba}$ & \multirow{3}{*}{$6.97 / 5.55$} \\
\hline & $\mathrm{N}-\mathrm{P}_{2} \mathrm{O}_{5}-\mathrm{K}_{2} \mathrm{O}$ & $5.86 \mathrm{Aa}$ & $6.30 \mathrm{ABa}$ & $5.66 \mathrm{Ba}$ & $5.68 \mathrm{Ba}$ & \\
\hline & Control & 6.06Aa & $6.07 \mathrm{ABa}$ & $5.92 \mathrm{Ba}$ & $5.46 \mathrm{Ba}$ & \\
\hline \multirow{3}{*}{ TGW } & FMS & $11.89 \mathrm{Aa}$ & $11.36 \mathrm{Ba}$ & $9.05 \mathrm{Ca}$ & $8.13 \mathrm{Da}$ & \multirow{3}{*}{$3.62 / 5.57$} \\
\hline & $\mathrm{N}-\mathrm{P}_{2} \mathrm{O}_{5}-\mathrm{K}_{2} \mathrm{O}$ & $12.37 \mathrm{Aa}$ & $10.98 \mathrm{Ba}$ & $8.60 \mathrm{Ca}$ & $7.85 \mathrm{Da}$ & \\
\hline & Control & $12.02 \mathrm{Aa}$ & $11.43 \mathrm{Ba}$ & $9.12 \mathrm{Ca}$ & $8.06 \mathrm{Da}$ & \\
\hline
\end{tabular}

${ }^{(1)}$ Means followed by equal letters, lowercase in the lines comparing water regimes (WRs) and uppercase in the columns comparing treatments, do not differ by Tukey's test, at 5\% probability. WR1, WR2, WR3, and WR4, equivalent to 100, 65, 44, and 28\% of crop evapotranspiration replacement, respectively. CV1, coefficient of variation related to treatments; and CV2, coefficient of variation related to water regimes.
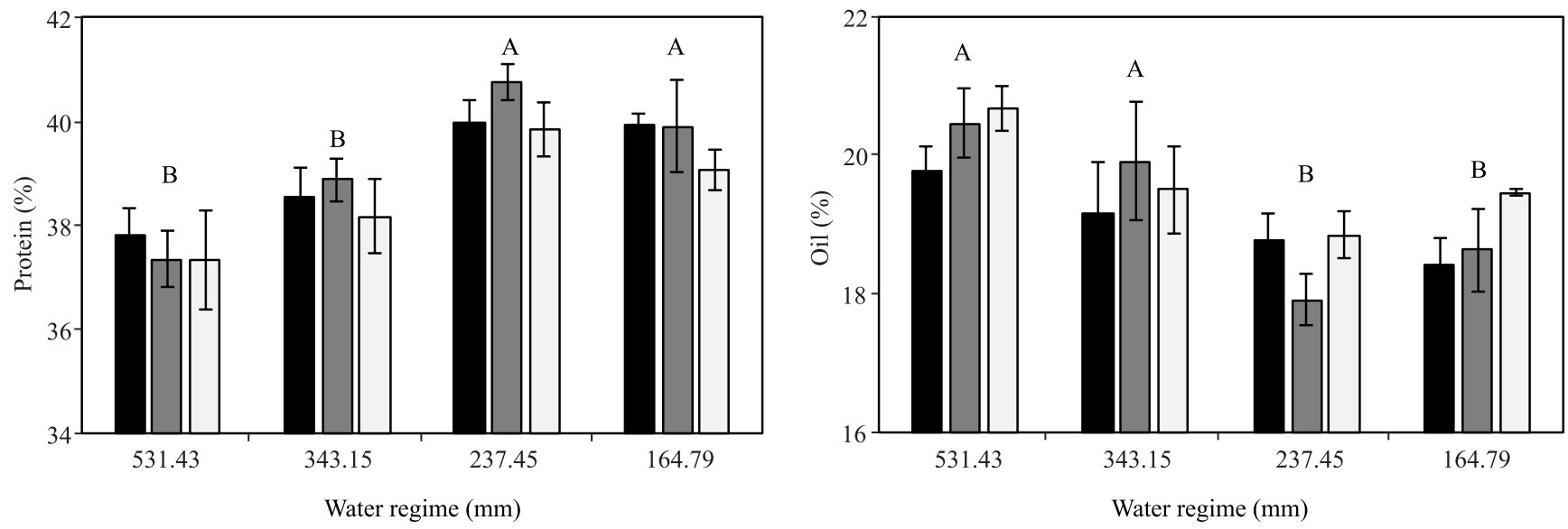

aMS $\square$ NPK $\square$ Control

Figure 3. Protein and oil abundance for fine-graded mica schist (FMS), N- $\mathrm{P}_{2} \mathrm{O}_{5}-\mathrm{K}_{2} \mathrm{O}$, and control treatments applied to soybean (Glycine max) subjected to water deficit. Means followed by equal letters do not differ statistically by Tukey's test, at $5 \%$ probability.

\section{Conclusions}

1. The presence of soil remineralizer does not affect most physiological parameters of soybean (Glycine $\max$ ) in the water levels evaluated in the experiments carried out in 2017 and 2018.
2. The effect of water levels on soybean plant physiology and grain quality is clear in the two experimental years, and drought reduces plant cycle independently of the $\mathrm{N}-\mathrm{P}_{2} \mathrm{O}_{5}-\mathrm{K}_{2} \mathrm{O}$, soil remineralizer, or control treatments. 
3. The deleterious effects of the simulated dry spells on soybean metabolism were not alleviated by the soil remineralizer after two years of application.

\section{Acknowledgments}

To Conselho Nacional de Desenvolvimento Científico e Tecnológico (CNPq), for the scientific productivity fellowships granted to the third author; and to the research group of Embrapa Cerrados, to University of Brasília, to Forschungszentrum Jülich, and to Instituto Federal Goiano - Campus Posse, for the possibility of a full dedication to obtaining a doctorate degree.

\section{References}

ACOMPANHAMENTO DA SAFRA BRASILEIRA [DE] GRÃOS: safra 2019/20: décimo segundo levantamento, v.7, n.12, set. 2020.

ALVARES, C.A.; STAPE, J.L.; SENTELHAS, P.C.; GONÇALVES, J.L. de M.; SPAROVEK, G. Köppen's climate classification map for Brazil. Meteorologische Zeitschrift, v.22, p.711-728, 2013. DOI: https://doi.org/10.1127/09412948/2013/0507.

BABAR, M.A.; REYNOLDS, M.P.; VAN GINKEL, M.; KLATT, A.R.; RAUN, W.R.; STONE, M.L. Spectral reflectance to estimate genetic variation for in-season biomass, leaf chlorophyll, and canopy temperature in wheat. Crop Science, v.46, p.10461057, 2006. DOI: https://doi.org/10.2135/cropsci2005.0211.

BAKER, N.R. Chlorophyll fluorescence: a probe of photosynthesis in vivo. Annual Review of Plant Biology, v.59, p.89-113, 2008. DOI: https://doi.org/10.1146/annurev.arplant.59.032607.092759.

BOARD, J.E.; KAHLON, C.S. Soybean yield formation: what controls it and how it can be improved. In: EL-SHEMY, H.A. (Ed). Soybean physiology and biochemistry. Rijeka: In Tech, 2011. p.1-36.

BORNHOFEN, E.; BENIN, G.; GALVAN, D.; FLORES, M.F. Épocas de semeadura e desempenho qualitativo de sementes de soja. Pesquisa Agropecuária Tropical, v.45, p.46-55, 2015. DOI: https://doi.org/10.1590/1983-40632015v4529143.

BURT, R. (Ed.). Soil Survey Field and Laboratory Methods Manual: soil survey investigations report $\mathrm{n}^{0}$ 51. version 2 . Lincoln: U.S. Department of Agriculture, Natural Resources Conservation Service, 2014.

CABRERA-BOSQUET, L.; CROSSA, J.; VON ZITZEWITZ, J.; SERRET, M.D.; ARAUS, J.L. High-throughput phenotyping and genomic selection: the frontiers of crop breeding converge. Journal of Integrative Plant Biology, v.54, p.312-320, 2012. DOI: https://doi.org/10.1111/j.1744-7909.2012.01116.x.
CATTELAN, A.J.; DALL'AGNOL, A. The rapid soybean growth in Brazil. Oilseeds \& Fats, Crops and Lipids, v.25, D102, 2018. DOI: https://doi.org/10.1051/ocl/2017058.

CHOUDHURY, F.K.; RIVERO, R.M.; BLUMWALD, E.; MITTLER, R. Reactive oxygen species, abiotic stress and stress combination. The Plant Journal, v.90, p.856-867, 2017. DOI: https://doi.org/10.1111/tpj.13299.

DAMATTA, F.M.; AVILA, R.T.; CARDOSO, A.A.; MARTINS, S.C.V.; RAMALHO, J.C. Physiological and agronomic performance of the coffee crop in the context of climate change and global warming: a review. Journal of Agricultural and Food Chemistry, v.66, p.5264-5274, 2018. DOI: https://doi.org/10.1021/ acs.jafc.7b04537.

EL-HENDAWY, S.; AL-SUHAIBANI, N.; SALEM, A.E.-A.; UR REHMAN, S.; SCHMIDHALTER, U. Spectral reflectance indices as a rapid nondestructive phenotyping tool for estimating different morphophysiological traits of contrasting spring wheat germplasms under arid conditions. Turkish Journal of Agriculture and Forestry, v.39, p.572-587, 2015. DOI: https://doi.org/10.3906/tar-1406-164.

ELSAYED, S.; DARWISH, W. Hyperspectral remote sensing to assess the water status, biomass, and yield of maize cultivars under salinity and water stress. Bragantia, v.76, p.62-72, 2017. DOI: https://doi.org/10.1590/1678-4499.018.

EMBRAPA. Empresa Brasileira de Pesquisa Agropecuária. Monitoramento de Irrigação no Cerrado. Brasília, 2011.

GAMON, J.A.; SERRANO, L.; SURFUS, J.S. The photochemical reflectance index: an optical indicator of photosynthetic radiation use efficiency across species, functional types, and nutrient levels. Oecologia, v.112, p.492-501, 1997. DOI: https://doi.org/10.1007/ s004420050337.

GENTY, B.; BRIANTAIS, J.-M.; BAKER, N.R. The relationship between the quantum yield of photosynthetic electron transport and quenching of chlorophyll fluorescence. Biochimica et Biophysica Acta (BBA) - General Subjects, v.990, p.87-92, 1989. DOI: https://doi.org/10.1016/S0304-4165(89)80016-9.

GHASSEMI-GOLEZANI, K.; LOTFI, R. Influence of water stress and pod position on oil and protein accumulation in soybean grains. International Journal of Agronomy and Plant Production, v.4, p.2341-2345, 2013.

HANKS, R.J.; KELLER, J.; RASMUSSEN, V.P.; WILSON, G.D. Line source sprinkler for continuous variable irrigationcrop production studies. Soil Science Society of America Journal, v.40, p.426-429, 1976. DOI: https://doi.org/10.2136/ sssaj1976.03615995004000030033x.

HARLEY, A.D.; GILKES, R.J. Factors influencing the release of plant nutrient elements from silicate rock powders: a geochemical overview. Nutrient Cycling in Agroecosystems, v.56, p.11-36, 2000. DOI: https://doi.org/10.1023/A:1009859309453.

JAYME-OLIVEIRA, A.; RIBEIRO JÚNIOR, W.Q.; RAMOS, M.L.G.; ZIVIANI, A.C.; JAKELAITIS, A. Amaranth, quinoa, and millet growth and development under different water regimes in the Brazilian Cerrado. Pesquisa Agropecuária Brasileira, v.52, p.561-571, 2017. DOI: https://doi.org/10.1590/S0100204X2017000800001 
KAR, R.K. Plant responses to water stress: role of reactive oxygen species. Plant Signaling \& Behavior, v.6, p.1741-1745, 2011. DOI: https://doi.org/10.4161/psb.6.11.17729.

LI, L.; ZHANG, Q.; HUANG, D.A. A review of imaging techniques for plant phenotyping. Sensors, v.14, p.20078-20111, 2014. DOI: https://doi.org/10.3390/s141120078.

MALEKIAN, A.; VALIZADEH, E.; DASTOORI, M.; SAMADI, S.; BAYAT, V. Soil water retention and maize (Zea mays L.) growth as effected by different amounts of Pumice. Australian Journal of Crop Science, v.6, p.450-454, 2012.

MARSCHNER, P. (Ed.). Marschner's mineral nutrition of higher plants. $3^{\text {rd }}$ ed. Amsterdam: Elsevier, 2012. 672p.

MARTINS, E. de S.; RESENDE, A.V. de; OLIVEIRA, C.G. de; FURTINI NETO, A.E. Materiais silicáticos como fontes regionais de nutrientes e condicionadores de solos. In: FERNANDES, R.C.; LUZ, A.B. da; CASTILHOS, Z.C. (Ed.). Agrominerais para o Brasil. Rio de Janeiro: CETEM, 2010. p.89-104.

MENEZES-SILVA, P.E.; SANGLARD, L.M.V.P.; ÁVILA, R.T.; MORAIS, L.E.; MARTINS, S.C.V.; NOBRES, P.; PATREZE, C.M.; FERREIRA, M.A.; ARAÚJO, W.L.; FERNIE, A.R.; DAMATTA, F.M. Photosynthetic and metabolic acclimation to repeated drought events play key roles in drought tolerance in coffee. Journal of Experimental Botany, v.68, p.4309-4322, 2017. DOI: https://doi.org/10.1093/jxb/erx211.

NOVÁK, V.; HLAVÁČIKOVÁ, H. Swelling and shrinking soils. In: NOVÁK, V.; HLAVÁČIKOVÁ, H. Aplied soil hidrology. Cham: Springer, 2019. p.253-262. (Theory and applications of transport in porous media, v.32). DOI: https://doi.org/10.1007/9783-030-01806-1_16.

PIERUSCHKA, R.; ALBRECHT, H.; MULLER, O.; BERRY, J.A.; KLIMOV, D.; KOLBER, Z.S.; MALENOVSKÝ, Z.; RASCHER, U. Daily and seasonal dynamics of remotely sensed photosynthetic efficiency in tree canopies. Tree Physiology, v.34, p.674-685, 2014. DOI: https://doi.org/10.1093/treephys/tpu035.

PIMENTEL, M.M. The tectonic evolution of the Neoproterozoic Brasília Belt, central Brazil: a geochronological and isotopic approach. Brazilian Journal of Geology, v.46, p.67-82, 2016. Suppl. 1. DOI: https://doi.org/10.1590/2317-4889201620150004.
PRATT, C.; KINGSTON, K.; LAYCOCK, B.; LEVETT, I.; PRATT, S. Geo-agriculture: reviewing opportunities through which the geosphere can help address emerging crop production challenges. Agronomy, v.10, art.971, 2020. DOI: https://doi.org/10.3390/agronomy10070971.

RIBEIRO, L. da S.; SANTOS, A.R. dos; SOUZA, L.F. da S.; SOUZA, J.S. Rochas silicáticas portadoras de potássio como fontes do nutriente para as plantas solo. Revista Brasileira de Ciência do Solo, v.34, p.891-897, 2010. DOI: https://doi.org/10.1590/S0100-06832010000300030.

SANTOS, H.G. dos; JACOMINE, P.K.T.; ANJOS, L.H.C. dos; OLIVEIRA, V.Á. de; LUMBRERAS, J.F.; COELHO, M.R.; ALMEIDA, J.A. de; ARAÚJO FILHO, J.C. de; OLIVEIRA, J.B. de; CUNHA, T.J.F. Sistema brasileiro de classificação de solos. 5.ed. rev. e ampl. Brasília: Embrapa, 2018. 356p.

SOUZA, F.N. da S.; OLIVEIRA, C.G. de; MARTINS, E. de S.; ALVES, J.M. Efeitos condicionador e nutricional de um remineralizador de solos obtido de resíduos de mineração. Revista Agri-Environmental Sciences, v.3, p.1-14, 2017.

SOUZA, F.N. da S.; SANTANA, A.P. de; ALVES, J.M.; SILVA, M.H.M. e. Efeitos de um remineralizador de solos (biotita-xisto) na produção de duas variedades de mandioca. Revista Raízes e Amidos Tropicais, v.12, p.45-59, 2016. DOI: https://doi.org/10.17766/1808-981X.2016v12n1p45-59.

THEODORO, S.H.; LEONARDOS, O.; ROCHA, E.L.; REGO, K.G. Experiências de uso de rochas silicáticas como fonte de nutrientes. Espaço \& Geografia, v.9, p.263-292, 2006.

WINIWARTER, V.; BLUM, W.E.H. From marl to rock powder: on the history of soil fertility management by rock materials. Journal of Plant Nutrition and Soil Science, v.171, p.316-324, 2008. DOI: https://doi.org/10.1002/jpln.200625070.

ZHANG, Q.; CHEN, J.M.; JU, W.; WANG, H.; QIU, F.; YANG, F.; FAN, W.; HUANG, Q.; WANG, Y.-P.; FENG, Y.; WANG, X.; ZHANG, F. Improving the ability of the photochemical reflectance index to track canopy light use efficiency through differentiating sunlit and shaded leaves. Remote Sensing of Environment, v.194, p.1-15, 2017. DOI: https://doi.org/10.1016/j.rse.2017.03.012. 